\title{
How will the new requirements to facilitate access to stakeholder schemes affect employers? \\ Received: 13th June, 2000
}

\section{lan Greenstreet}

is a senior pensions solicitor at Simmons \& Simmons and advises trustees and employers in relation to all legal issues relating to occupational pension schemes. He wrote the section on stakeholder pensions in 'The Law of Pension Schemes' by Sweet \& Maxwell (currently being updated) and has been commissioned to write a special report on stakeholder pensions also to be published by Sweet \& Maxwell. He is a regular speaker at conferences, recently speaking on stakeholder and the employer, and pension scheme mergers.

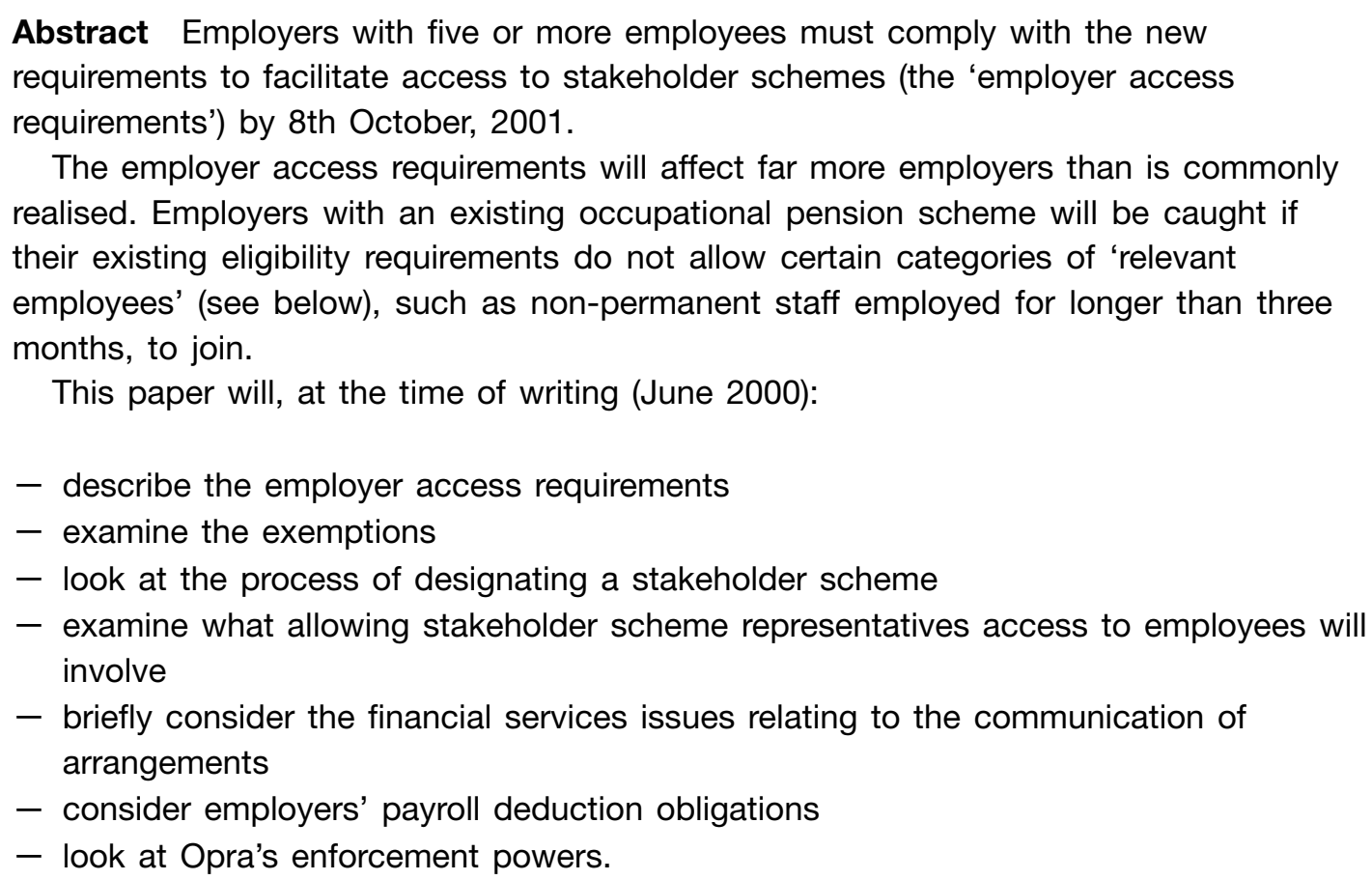

Keywords: stakeholder pension schemes; employer access requirements; eligibility

lan Greenstreet

(Simmons and Simmons, 21 Wilson Street, London EC2M 2TX

Tel: +44 (0)20 7825 4090; Fax: +44 (0)20 7628 2070; e-mail:

ian.greenstreet@simmonssimmons.com)

\section{Introduction}

Most employers with occupational pension schemes will be affected by the new requirements to facilitate access to stakeholder schemes (the 'employer access requirements') as they will have categories of 'relevant employees' such as non-permanent contract staff who are not currently eligible to join the scheme.
Employers with existing occupational pension schemes will need to review their existing eligibility rule and consider whether to:

— widen the existing eligibility requirements to take themselves outside the scope of the new requirements (this might include offering the employees 
who are eligible for the first time a lower level of benefit in the occupational pension scheme); or

- keep the eligibility requirements as they are but designate a stakeholder scheme and comply with the employer access requirements in relation to any 'relevant employees' who are currently not eligible to join the occupational pension scheme; or

- replace the existing occupational pension scheme with a personal pension scheme to which the employer contributes at least 3 per cent of basic salaries and operate the payroll deduction facility in accordance with the above requirements, or designate a stakeholder scheme and comply with the employer access requirements in relation to such a scheme.

Employers with existing group personal pension schemes will need to review the terms of those schemes and consider whether the terms can be altered to take them outside the scope of the new requirements before 8th October 2001. Contracts of new employees after that date may need to be altered if this exemption is to be relied on. The Government intends to review whether to retain this exemption in about 3 years' time.

Employers with no existing pension provision will have three main options:

- set up an occupational pension scheme for their employees;

- contribute to a sufficiently good personal pension scheme (meeting the new statutory requirements) at a rate of at least 3 per cent of their employees' basic salaries; or

- designate a stakeholder scheme and operate the employer access requirements in relation to their employees to whom the two options above do not apply.

\section{Employer access requirements: What are they?}

The employer access requirements apply only to employers with 'relevant employees (see below). The requirements are set out in section 3 of the Welfare Reform and Pensions Act 1999 (WRPA) and are as follows:

\section{(A) Designation of stakeholder} scheme. First, the employer, after consulting with its relevant employees and any other organisations representing them, has to designate one or more stakeholder schemes which (or at least one of which) offers membership to all of those employees (section 3(2) WRPA);

(B) Information. Secondly, the employer has to supply its relevant employees with the name and address of the designated scheme or schemes and such other information as may be prescribed in regulations (section 3(3) WRPA);

(C) Access. Thirdly, the employer is required to allow representatives of the designated scheme or schemes reasonable access to its relevant employees for the purpose of supplying them with information about the designated scheme or schemes (section 3(4) WRPA);

(D) Payroll deduction facility. Fourthly, the employer, if requested by a relevant employee who is a member of a qualifying scheme, must deduct contributions from the employees' remuneration and pay them to the trustees or managers of the scheme or, if the regulations so provide, to a prescribed person (section 3(5) of the WRPA). A 'qualifying scheme' is a designated stakeholder scheme or one of the designated schemes or, if the regulations so provide, any other stakeholder scheme. Currently the 
Government has no intention of requiring employers to operate the payroll deduction facility in relation to stakeholder schemes, other than stakeholder scheme designated by the employer for this purpose.

(E) Stakeholder scheme ceases to be registered. The fifth requirement is that if a designated stakeholder scheme ceases to be registered with Opra, the employer must withdraw its designation (section 3(5) WRPA). It then has up to four months to designate a new one.

The employer access requirements will not apply to existing employers until Monday 8th October, 2001. This delay is designed to give employers sufficient time to designate a stakeholder scheme and set up the payroll deduction arrangements following the introduction of stakeholder schemes in April 2001.

If the employer access requirements apply to an employer for the first time after 8th October, 2001, an employer will have three months to select a scheme that it wishes to designate and complete the designation process (The Stakeholder Pension Scheme Regulations 2000 No. 1403 (the 'Stakeholder Regulations') Regulations 22(9)(a) and (c)).

Employers will also have three months to select and complete the designation process of a scheme after employing a fifth employee in the period from 8th July to 8th October, 2001 (Stakeholder Regulation 22(9)(b)).

\section{The exemptions from the employer access requirements}

An employer only has to comply with the employer access requirements if it has 'relevant employees'. 'Relevant employees' are all the employees of the employer employed in Great Britain and also, in the case of an employer resident or incorporated in any part of Great Britain, all employees employed outside the United Kingdom except:

- any employees whose employment qualifies them for membership of an occupational pension scheme of an employer (definition of relevant employees in section 3(9) of WRPA);

- any employees whose earnings fall below the lower earnings limit for national insurance purposes in any one or more weeks within the last three months (Stakeholder Regulation 23(1)(e));

- any employee whose employment would qualify him for membership of an occupational pension scheme of the employer had he been employed for more than 12 months (Stakeholder Regulation 23(1)(a));

- any employee whose employment would qualify him for membership of an occupational pension scheme of the employer if he was over age 18 or more than five years below the normal pension age for that scheme (Stakeholder Regulation 23(1)(b));

- any employee who was eligible to join an occupational scheme of an employer in the past but is now excluded as he did not join at that time (Stakeholder Regulation 23(1)(c));

- any employee who has been employed by the employer for a continuous period of less than three months (Stakeholder Regulation 23(1)(d)); and

- any employee who is ineligible by virtue of any enactment relating to tax or any restriction imposed by the Inland Revenue to make contributions to a stakeholder scheme (Stakeholder Regulation 23(1)(f)).

Employers also need not comply with 
the employer access requirements if they have fewer than five employees.

In addition, employers need not comply with the employer access requirements if it is:

(A) a term of the contract of employment of every relevant employee (other than an employee who has not attained the age of 18) that:

1 The employer will contribute to a personal pension scheme chosen by the employer at the rate of at least 3 per cent of basic pay for any period for which the employee, while in employment, is a member of that scheme. Any employer contributions must be made on each occasion that the employee is paid by the employer (or if the employee and employer agree, at longer intervals);

2 The employer must, if he is requested to do so by the employee, deduct the employee's contributions to that scheme from his remuneration and pay them to the trustees or managers of that scheme;

(B) No charge or penalty is imposed by the personal pension scheme on any member for transferring all or any of his funds out of that scheme or for ceasing to contribute to that scheme.

The employer contributions may be made conditional on the employee making contributions to the same scheme and at the same intervals as the employer (or if the employer and employee agree at longer intervals) at a specified rate not exceeding 3 per cent of basic pay for each such interval.

There are special provisions that will apply where an employer is already contributing to a personal pension scheme on behalf of its employees. If an employer can provide written evidence to show that contributions are being made and have continuously been made from a date prior to 8th October, 2001 as if each relevant employee had a term in his contract that would satisfy the requirements described in paragraph $\mathrm{A}$ above, it will not be necessary to amend the existing contracts of the relevant employees (Stakeholder Regulation 22(8)).

This is a useful relaxation of the requirements, as typically existing employment contracts will not impose a contractual obligation on the employer to make contributions to a personal pension scheme. The circumstances in which an employer can rely on the exemption is discussed in more detail below.

The Government has indicated that it will review the above exemption in three years' time at the same time as it reviews the exemption for employers with fewer than five employees.

\section{Widening the scheme's eligibility rule?}

An employer with an existing occupational pension scheme will need to decide whether to avoid the new employer access requirements by altering the scheme's eligibility requirements so that it no longer has any relevant employees. The main alternative is to leave the eligibility requirements as they are and to designate a stakeholder scheme for any relevant employees who are not eligible to join the occupational pension scheme.

An employer will need to weigh up the practical difficulties of putting systems into place to identify and operate the employer access and payroll deduction requirements in relation to employees who are currently excluded against the cost and administrative complications associated of offering them membership. 
It may be useful now to consider whether employers are likely to want to relax some typical eligibility restrictions:

- lower age restriction. Many schemes will have an existing age restriction higher than 18. Many employers will be prepared to lower this age restriction;

- upper age restriction. Many schemes will also have an upper age limit preventing employees joining the scheme if they are employed for the first time within five years of the scheme's normal retirement date. This type of upper age limit is permissible under the Stakeholder Regulations;

- waiting periods. Many schemes will have waiting periods before employees are eligible to join the scheme. However, a waiting period of up to 12 months is permissible under a scheme's eligibility requirements before someone is treated as a relevant employee. Consequently, most schemes with waiting periods should not need to change their eligibility requirements;

\section{- minimum hours requirement.}

Many schemes used to have a minimum hours requirement that excluded part-timers from joining the scheme eg, an employee had to work at least 20 hours a week before he could join. However, most scheme eligibility rules removed the minimum hours requirement for part-timers by 1994 or 1995 at the latest, because of the risk of sex equality claims. From 1st July, 2000 it is no longer necessary for a part-timer to show indirect sex discrimination to argue that such an exclusion is unlawful. It will be unlawful to discriminate against part-timers under The Part-time Workers (Prevention of Less Favourable Treatment) Regulations, unless there are objective reasons for doing so. Schemes should therefore review any minimum hours restriction if they have not already done so;

- non-permanent staff restriction.

Many employers will have nonpermanent staff who are employed for more than three months and so will fall within the definition of relevant employees. Employers may be reluctant to widen the scheme eligibility rule to allow such employees to join. However, in practice it is unlikely that such employees would want to join an occupational pension scheme, particularly if there is a long waiting period (up to 12 months is permitted - see above) or if there is a two-year vesting period before early leavers are entitled to preserved benefits. Many non-permanent staff will be on fixed-term contracts. By 28th June, 2001 new legislation will have to be introduced implementing a European Directive on fixed-time work preventing the less favourable treatment of fixed-term workers than comparable permanent workers solely because they have a fixed-term contract, unless justified on objective grounds. So it may in any event be an appropriate time to review any restrictions relating to non-permanent staff;

- lower earnings restrictions. Some schemes have a lower earnings eligibility restriction. If this corresponds to the lower earnings limit it will be permissible. However, in practice it will still be necessary to put in place systems to monitor when earnings exceed this limit to ensure that the employer access requirements are complied with if an employees' earnings exceed the lower earnings limit for longer than three months;

- non-UK employee restriction. Many schemes will either exclude employees of a UK company sent 
abroad on secondment from membership, or make such membership subject to Trustee and Company consent where such continued membership is permissible under Revenue requirements. The definition of relevant employee includes all employees of an employer resident in or incorporated in any part of the United Kingdom that are employed outside the United Kingdom. There is an exemption for any employee who is ineligible by virtue of any enactment relating to tax or any restriction imposed by the Inland Revenue to make contributions to a stakeholder scheme. However, employees who have moved abroad will be able to continue to contribute to a stakeholder scheme for five years. Some thought will therefore need to be given as to whether such employees sent abroad should continue to be eligible to remain in the occupational pension, or whether a stakeholder scheme should be designated in respect of such employees. In practice this will be an issue only if they are not eligible to join another non-UK occupational pension scheme of the employer;

- employees of a non-resident group company not participating in the UK occupational scheme of the group. Any employees of an overseas employer employed in Great Britain are potentially caught by the new employer access requirements. A group of employers will not necessarily want these employees to be eligible to join the main UK group occupational, so may have to comply with the employer access requirements in relation to such employees while these employees are in the United Kingdom. In practice this will again be a problem only if they are not eligible to join another non-UK occupational pension scheme of the employer;
- employees excluded from membership if they do not join at the first opportunity. Many occupational pension schemes will not permit employees to join the scheme or make joining the scheme subject to employer and trustee consent and a medical examination if they do not join at the first opportunity. The Stakeholder Regulations permit such a restriction to be retained.

\section{Offering employees life cover to escape the employer access requirements}

Under the WRPA there is a general exclusion from the definition of relevant employee for any employees whose employment qualifies them for membership of an occupational pension scheme. An employee who is covered for lump sum death-in-service cover under an occupational pension scheme only providing death-in-service benefits or lump sum death-in-service cover of, say, one times salary, under the trusts of the main scheme will not be relevant employees. Under the WRPA it is, therefore, currently possible to avoid the employer access requirements by offering all employees life cover under the trusts of an occupational pension scheme.

The DSS is aware of this oversight/loophole in the primary legislation and is currently considering what should be done about it. It is therefore unlikely that employers will be able to take advantage of this loophole to avoid the new obligations to facilitate access to a stakeholder scheme.

Even if this loophole is closed there is nothing in the current legislation which requires a minimum level of benefits to be provided for employees under an occupational pension scheme. So a separate section offering lower benefits could be opened for them. 


\section{Escaping the employer access requirements by contributing to personal pension schemes}

Many providers have suggested that employers should set up group personal pension schemes meeting the requirements described above to escape the employer access requirements.

If the scheme is set up before 8th October, 2001 and the employer can provide written evidence to show that contributions are being made, and have been continuously made since a date before 8th October, 2001, as if each relevant employee had a term in his contract complying with the requirements described above, it is not necessary to amend the contracts (Stakeholder Regulation 22(8)).

The drafting of this exemption leaves a lot to be desired. The exemption does not expressly state that it is intended to apply only to pre-8th October, 2001 employees. The DSS has confirmed that the intention was that employers should ensure that new (post-8th October, 2001) employees have a contractual right to such a contribution and a contractual right to a payroll deduction facility to remain outside the scope of the employer access requirements. In practice it is likely that the Courts will interpret the exemption in a manner that is consistent with the DSS' interpretation, although contrary interpretations are arguable. So employers should ensure that new employees' contracts are changed.

There are also other areas of uncertainty. It is arguable, for example, that an employer will still be within the exemption in relation to pre-8th October, 2001 relevant employees if the existing personal pension scheme to which contributions are made before, on and after 8th October, 2001 has discontinuance penalties. So it may not be necessary to terminate an existing contract with the provider for pre-8th
October, 2001 employees (triggering the discontinuance penalties) and set up a new one without discontinuance penalties for such employees in respect of post-7th October, 2001 service. This may have been intended by the DSS. However, there is no discussion of this in the covering notes issued by the DSS.

The DSS has also inserted at a late stage a Regulation designed to clarify exactly what a discontinuance or termination penalty is (Stakeholder Regulation 22(7)). Again, this is not the easiest of regulations to interpret. Given the huge variety of existing penalties and charging structures that exist in personal pension schemes, this uncertainty could pose problems for employers as employers will need to satisfy themselves that any particular charge in a personal pension scheme is not a non-permissible charge or penalty that takes the employer outside the scope of the exemption.

\section{Designation of stakeholder scheme}

Employers will have to designate one or more stakeholder schemes at least one of which offers membership to all its relevant employees.

Before designating a scheme the employer has to consult with its relevant employees and any organisations representing them. These would include any trade unions or staff associations.

The Stakeholder Regulations do not provide for the possibility of consultation taking place on a Group-wide basis. So each company in a Group of employers would have to consult its own employees and theoretically may end up with different stakeholder schemes, depending on the results of the consultation exercise. In practice it may be possible to get round this problem by appointing one company in the group or one person as agent for all the other 
companies in the group, for the purposes of the consultation exercise.

\section{Employer liability in relation to designation}

An employer is not, whether before designating a scheme or at any time while a scheme is designated, under any duty to investigate or monitor, or make any judgment as to the past, present or future performance of the scheme (section 3(8) of the WRPA).

Consequently, if an employer picked a stakeholder scheme at random out of the list of stakeholder schemes registered with Opra, it should not be liable if the scheme's investments perform badly. However, this does not mean that there will not be employer relations problems if a poorly performing scheme is chosen. Most responsible employers will want to take independent financial advice before making a decision on which stakeholder scheme to designate. Also, employers will want to ensure that the provider has efficient administration systems that interface properly with their payroll systems.

If an employer takes it upon itself to investigate or monitor or make a judgment on the performance of its designated scheme, it could be liable if it acts negligently. In practice, if it takes due care in the selection of the adviser and acts on any advice obtained it should not have any exposure if the scheme performs badly.

\section{What will the obligation to allow representatives of the stakeholder scheme reasonable access involve?}

Giving any relevant employees the name and address of the designated stakeholder scheme or schemes, and any prescribed information about the scheme (none seems to have been prescribed yet), should not be particularly onerous.

Providers are likely to want to make on-site presentations to employees only where there are a reasonable number of relevant employees on one site. Site visits are likely to involve a presentation about the stakeholder scheme. Scheme information packs about the arrangements including a Financial Services Authority decision tree and generic projections of benefits are also likely to be distributed.

Most providers will not offer individual financial advice to employees about the arrangements unless the employees are willing to pay a separate fee for this advice, which is unlikely. The site visits are likely to be backed up by a telephone and/or web-based information service about the pension arrangements.

Where there are only a few relevant employees on multiple sites it is likely that all that will be provided is access to a telephone and web-based information service.

\section{Financial services issues for employers: What can you tell your employees about your designated stakeholder scheme?}

Under the Financial Services and Markets Bill (which should be in force by the time stakeholder is introduced), there will be a general prohibition on unauthorised persons carrying out regulated activities in the United Kingdom. Contravention of the general prohibition is a criminal offence.

Regulated activities will include being in the business of 'arranging deals for another' (which might in certain circumstances include referring employees to a stakeholder provider) and giving 'investment advice' (which might in certain circumstances include advising on the merits of a stakeholder scheme). 
Employers therefore need to be careful that they do not put themselves in breach of these requirements.

In practice employers should not be caught by FSA requirements if all they do is designate a stakeholder scheme and give the employees factual information about the scheme. The Government also believes that there is already scope within the existing regime to offer employees some further help and guidance in interpreting information about the designated stakeholder scheme.

Employers will also be able to give general advice if they do not focus on the merits of a particular scheme.

The Government considers that if an employer goes further and recommends the designated stakeholder scheme, this would count as 'investment advice' and the employer would need to be authorised. Although it would be advisable to follow the Government's interpretation of the legislation, it is debatable whether the Government is correct as the employer will not be giving the advice in the course of business unless it does so for direct (eg, a commission) or indirect financial gain (eg, reduced rates on other products).

However, regardless of the Financial Services position, it is not a good idea not to give advice on the merits of a particular stakeholder scheme because of the subsequent risk of claims from employees for negligence if the scheme investments perform badly. The protection described above will not protect an employer if it negligently advises its employees to join its stakeholder scheme on the grounds that it is the best one on the market if it is not reasonable for the employer to form this view.

Unauthorised persons will also be prohibited from issuing financial promotions unless the content of the promotion is approved by an authorised person or an exemption applies (Clause
19 of the Financial Services and Markets Bill). Consequently, it may be necessary to obtain the approval of an authorised person to any material issued about the designated stakeholder scheme or arrange for it to be issued by the provider or an independent financial intermediary.

\section{Payroll deduction facility: starting, varying and ceasing contributions}

Employers will have to operate a payroll deduction facility in respect of a relevant employee who joins the designated stakeholder scheme and requests to use this facility (section 3(5) WRPA). However, it is up to the employee to decide whether to contribute to the scheme using the payroll deduction facility.

Currently the intention is that employers will only be required to make payroll deductions to the designated stakeholder scheme. However, the Government has left open the possibility that clearing arrangements will be developed once stakeholder schemes become established.

An employer is only required to comply with a request to change the rate at which contributions are deducted from his salary every six months. The employer must comply with such a request as soon as possible but no later than the end of the pay period following the date that the request is made (Stakeholder Regulation 24(1)).

As a quid pro quo for this flexibility, an employer will have to give its employees various information about when the employer does and does not have to deduct contributions in the future at the time: when the employee first requests to make contributions under the payroll deduction facility (Stakeholder Regulation 25(2)); at the time when the employee varies the rate of contributions less than 
six months after a previous request and the employer decides not to comply with the request (Stakeholder Regulation 24(2)) and at the time when an employee requests a termination of his contributions (Stakeholder Regulation 24(3)).

These requirements are likely to be burdensome to operate.

\section{Payroll deduction requirements: Payment of contributions to stakeholder scheme}

Stakeholder schemes that qualify as occupational pension schemes will be subject to the usual requirements applicable to occupational money purchase pension schemes in relation to the payment of employee and employer contributions. Broadly, employers have to pay over any employee contributions that are deducted from salary within 14 days from the end of the income tax month in which they are deducted in the case of minimum payments, and 19 days of the end of the calendar month in which they are deducted in the case of other employee contributions (section 49(8) of the Pensions Act 1995 as amended by section 10 WRPA).

Employer contributions must be paid by the due dates specified in the payment schedule that trustees are required to prepare in relation to money purchase schemes. Opra must be notified by the trustees within 30 days of a failure to pay over contributions to the scheme, and the members must be notified by the trustees within 90 days if the contributions are not made within 60 days of the due date (Regulation 20 of The Occupational Pension Schemes (Scheme Administration) Regulations 1996). However, since 30th December, 1999 no notification needs to be given to Opra if payment is made within ten days of the due date and the default is only the first or second such default in the 12-month period ending on the due date.

Stakeholder schemes that qualify as personal pension schemes and other personal pension schemes to which payments are made directly by the employer on behalf of the employee will be subject to very similar requirements. Under the new requirements (section 111A Pension Schemes Act 1993 to be inserted by section 9 WRPA and the Draft Employer Payments to Personal Pension Schemes amending the Personal Pension Schemes (Disclosure of Information) Regulations SI 1987/1110) broadly:

\section{- Employer contribution record.}

The employer has to secure that there is prepared, maintained and from time to time revised, a record of the direct payment arrangements that shows the rates and due dates of the contributions payable under the direct payment arrangements. Separate entries are required for the rates of employee contributions deducted from salary and employer contributions. The employer will therefore need to update the record every time a new employee joins or leaves the scheme or changes the rate at which he contributes;

- due dates. The due date for employee contributions is 19 days after the end of the month in which they are deducted from salary. So if the contributions are deducted in January they must be paid over by 19th February. The due date for the payment of the employer's contribution will be the date inserted by the employer into the contribution record. It could be different from the due date for the payment of employee contributions;

- employer contribution record to be made available to trustees or 
managers. The employer has to supply a copy of the record to the trustees or managers no later than the date the first contribution that is payable by reference to that record is due;

- time limits for giving notice of non-payment to Opra. If contributions are not paid by the due date specified in the record the trustees or managers of the stakeholder scheme must give notice of the late payment to:

1 Opra within 30 days commencing on the day after the due date; and

2 the member before the end of 90 days commencing on the day after the due date, unless payment has been made before the end of 60 days commencing with the day after the due date.

There is some leeway in the reporting requirements as Opra does not have to be notified where payment is made within ten days of the day following the due date and the default is either the first or second default by that employer in the period of 12 months ending with that due date. If there are further defaults which result in an Opra notification, details of any defaults in the previous 12 months would also then have to be given.

\section{Opra's enforcement powers: Finance directors and payroll managers beware}

Opra has wide-ranging enforcement powers including powers to levy civil penalties and to commence criminal proceedings in relation to certain offences.

Where Opra is satisfied that any person has become liable to a civil penalty, it may by written notice require that person to pay a penalty. The amount of the penalty is at Opra's discretion. However, an individual cannot currently be required to pay more than $£, 5,000$ and corporate bodies more than $£ 50,000$ for each breach (section 10(2) Pensions Act 1995).

Employers can also in certain circumstances be convicted of criminal offences for breach of certain requirements. Opra institutes prosecutions for these offences. Criminal and civil penalties cannot both be imposed in relation to the same act or omission.

If a company commits a specified criminal offence under the Pensions Act 1995, its directors, managers and other officers are also liable if the criminal act was committed with their consent or connivance or was attributable to their neglect (section 115(1) Pensions Act 1995).

Similarly any director, manager, secretary or other similar officer of a company who consented or who connived in an act or omission, or the company to whose neglect the act or omission was attributable is liable to a civil penalty if the company could itself be subject to a penalty (section 10(5)(b) and (6)(a)(i) Pensions Act 1995). So a finance director or payroll manager who neglects to ensure that contributions are paid over in time could be liable. However, where such a penalty is imposed, a penalty cannot also be imposed on the company for the same offence (section 10(7) Pensions Act 1995).

An employer can be subject to civil penalties if it fails to comply with any of the requirements to facilitate access to a stakeholder scheme described in Employer Access Requirements A, B, C and D (section 3(7) WRPA). Employers can also be liable to penalties if they fail, in relation to a stakeholder personal pension scheme: 
- to take all steps as are reasonable to prepare a record of the direct payment arrangement or keep it up to date (section 111A (8)(a) Pension Schemes Act 1993 to be inserted by section 9 WRPA);

- to take all steps as are reasonable to send the record to the provider (section 111A (8)(a) Pension Schemes Act 1993 to be inserted by section 9 WRPA);

- to make the correct payments by the due date (section 111A (8)(b) Pension Schemes Act 1993 to be inserted by section 9 WRPA).

An employer will be guilty of a criminal offence if he is knowingly concerned in the fraudulent evasion of the direct payment arrangements for the deduction of employee's contributions (section 111A(12) Pension Schemes Act 1993 to be inserted by section 9 WRPA). In the past a lot of employers that were in financial difficulty used employee contributions to help keep a company afloat. If a finance director does this now, he risks criminal prosecution.

Employers who do not pay over the employee contributions to an occupational stakeholder pensions scheme are subject to similar sanctions.

\section{What options do employers have to comply with the new requirements?}

To sum up, employers with existing occupational pension schemes will need to review their existing eligibility rule and consider whether to:

— widen the existing eligibility requirements to take themselves outside the scope of the new requirements (this might include offering the employees who are eligible for the first time a lower level of benefit in the occupational pension scheme); or

- keep the eligibility requirements as they are, but designate a stakeholder scheme and comply with the employer access requirements in relation to any 'relevant employees' who are currently not eligible to join the occupational pension scheme; or

- replace the existing occupational pension scheme with a personal pension scheme to which the employer contributes at a rate of at least 3 per cent of its employees' existing salary and operates the payroll deduction facility in accordance with the above requirements or designate a stakeholder scheme and comply with the employer access requirements in relation to such a scheme.

Employers with existing group personal pension schemes will need to review the terms of those schemes and consider whether the terms can be altered to take them outside the scope of the new requirements before 8th October, 2001. Contracts of new employees after that date may need to be altered if this exemption is to be relied on. The Government intends to review whether to retain this exemption in about three years' time.

Employers with no existing pension provision will have three main options:

- to set up an occupational pension scheme for their employees;

- to contribute to a sufficiently good group personal pension scheme (meeting the new statutory requirements) at a rate of at least 3 per cent of its employees' basic salaries; or

— to designate a stakeholder scheme and operate the employer access requirements in relation to its employees to whom the above two options do not apply. 